\title{
ANALISIS PENGARUH BAURAN PEMASARAN JASA TERHADAP KEPUTUSAN SISWA MEMILIH SMK NEGERI 1 SUMBAWA BESAR (STUDI KASUS ANGKATAN 2017/2018)
}

\author{
ANALYSIS OF THE EFFECT OF SERVICE MARKETING MIX ON \\ STUDENTS'DECISION TO CHOOSE SMK NEGERI 1 SUMBAWA BESAR \\ (ANGKATAN 2017/2018).
}

\author{
Arlini Yuniarsih ${ }^{1}$, Lukmanul Hakim ${ }^{2}$, Yandri Sudodo ${ }^{3}$ \\ Departemen Manajemen, Fakultas Ekonomi dan Bisnis, Universitas Teknologi Sumbawa
}

*) E-mail: yuniarsiharlini6@gmail.com

\begin{abstract}
This study aims to analyze the effect of Service Marketing Mix on Student Decisions in Choosing SMK 1 Sumbawa Besar. This paper use assosiative quantitative method to analysis the effect. The data use obtain by questionnaire sourced from the agency. Sampling was done by probability random sampling and obtained a sample of 150 students of SMK Negeri 1 Sumbawa Besar. The results showed that the product had no effect and was not significant on the decision of students choosing SMK Negeri 1 Sumbawa Besar, price variable had no effect and was not significant on the decision of students choosing SMK Negeri 1 Sumbawa Besar, promotion variable had no effect and was not significant of student decision to choose SMK Negeri 1 Sumbawa Besar, place variable had effect and was not significant to the decision of students choosing SMK Negeri 1 Sumbawa Besar, people have influence and was not significant to the decision of students choosing SMK Negeri 1 Sumbawa Besar, process variable had no effect and was not significant to the decision of students choosing SMK Negeri 1 Sumbawa Besar, and physical evidence variable has a significant effect on the decision of students choosing SMK Negeri 1 Sumbawa Besar.
\end{abstract}

Keywords: Products, Prices, Promotions, Places, People, Processes and Physical Evidence.

\begin{abstract}
ABSTRAK
Penelitian ini bertujuan untuk menganalisis pengaruh Bauran Pemasaran Jasa terhadap Keputusan Siswa Memilih SMK Negeri 1 Sumbawa Besar. Metode analisis yang digunakan yaitu metode kuantitatif Asosiatif. Teknik analisis data yang digunakan dalam penelitian ini yaitu analisis regresi linier berganda. Data yang digunakan yaitu data sekunder dan data primer. Pengumpulan data diambil dengan cara kuesioner yang bersumber dari instansi tersebut. Pengambilan sampel dilakukan secara probability random sampling dan diperoleh sampel sebanyak 150 siswa-siswi SMK Negeri 1 Sumbawa Besar Angkatan 2017/2018. Hasil penelitian menunjukkan bahwa Produk tidak berpengaruh dan tidak signifikan terhadap keputusan siswa memilih SMK Negeri 1 Sumbawa Besar, Harga tidak berpengaruh dan tidak signifikan terhadap keputusan siswa memilih SMK Negeri 1 Sumbawa Besar Angkatan 2017/2018, promosi berpengaruh dan tidak signifikan terhadap keputusan siswa memilih SMK Negeri 1 Sumbawa Besar Angkatan 2017/2018, Tempat berpengaruh dan tidak signifikan terhadap keputusan siswa memilih SMK Negeri 1 Sumbawa Besar Angkatan 2017/2018, Orang berpengaruh dan tidak signifikan terhadap keputusan siswa memilih SMK Negeri 1 Sumbawa Besar Angkatan 2017/2018, Proses tidak berpengaruh dan tidak signifikan terhadap keputusan siswa memilih SMK Negeri 1 Sumbawa Besar Angkatan 2017/2018, variabel Bukti Fisik berpengaruh signifikan terhadap keputusan siswa memilih SMK Negeri 1 Sumbawa Besar 2017/2018.
\end{abstract}

Kata Kunci: Produk, Harga, Promosi, Tempat, Orang, Proses dan Bukti Fisik.

\section{PENDAHULUAN}

Perkembangan di ilmu pengetahuan dan teknologi sekarang menuntut masyarakat untuk mampu melakukan perubahan dan mengikuti perkembangan pendidikan yang ada. Masyarakat juga harus mampu bersaing di dunia kerja yang lebih kompeten (Tangilisan et al, 2014). Pendidikan adalah alat yang strategis untuk meningkatkan mutu sumber daya masyarakat. Pendidikan juga adalah ilmu yang dapat kita pelajari dan bisa menjadikan manusia cerdas, memiliki kemampuan, sikap yang baik dan dapat berinteraksi dengan baik dikalangan masyarakat. Dilembaga pendidikan terutama sekolah adalah untuk menambah ilmu pengetahuan akan tetapi tujuan lain dari lembaga pendidikan yaitu untuk mencapai kepuasan pelanggan. Banyaknya lembaga pendidikan yang bersaing menawarkan jasa pendidikan kepada masyarakat untuk menarik minat calon siswa. Dalam rangka meningkatkan persaingan antar sekolah lain diperlukan strategi pemasaran jasa pendidikan yang baik untuk mengenalkan sekolah kepada calon siswa-siswi. 
Banyaknya sekolah menengah kejuruan dengan segala penawaran, tentu membuat masyarakat selaku konsumen yang ingin melanjutkan ke jenjang yang lebih tinggi seperti SMA maupun SMK harus memikirkan dengan banyak pertimbangan dalam menentukan berbagai pilihan sekolah hingga proses memilih jurusan yang sesuai untuk dirinya sendiri.

Sekolah menengah kejuruan merupakan jembatan bagi masyarakat untuk menuntut ilmu serta melatih kemampuan agar menjadi SDM yang berkualitas dibidangnya, SMK merupakan sekolah dengan tujuan memberikan bekal siap kerja pada siswa yang terampil tingkat menengah sesuai dengan persyaratan yang dituntut oleh dunia kerja Wati (2014). Di Sumbawa terdapat masalah pada saat pendaftaran siswa baru, salah satunya yaitu sebagian besar orang tua siswa yang berminat untuk menyekolahkan anaknya ke jenjang pendidikan tertentu, namun kadang kala tidak sesuai dengan kemampuan yang dimiliki oleh calon siswa itu sendiri. Banyaknya faktor yang memengaruhi keputusan siswa ataupun orang tua dalam memilih instansi pendidikan sebagai tempat mereka bersekolah yaitu seperti produk, harga, promosi, lokasi, orang, proses dan bukti fisik yang ada disuatu sekolah bisa menjadi pertimbangan calon siswa baru dalam memilih sekolah.

Semakin tingginya persaingan di dunia kerja, tidak sedikit orang pada saat ini memilih sekolah kejuruan. Alasannya karena sekolah kejuruan bisa memberikan bekal kecakapan hidup berdasarkan potensi dan kopetensi yang dibutuhkan oleh dunia kerja. SMK Negeri 1 Sumbawa Besar banyak diminati oleh calon siswa akan tetapi strategi bauran pemasarn jasa yang dilakukan oleh SMK Negeri 1 Sumbawa Besar masih kurang.

\section{Rumusan Masalah}

Berdasarkan latar belakang, maka dapat dirumuskan beberapa masalah yang akan diteliti sebagai berikut :

1. Bagaimana pengaruh produk terhadap keputusan siswa memilih SMK Negeri 1 Sumbawa Besar Angkatan 2017/2018?

2. Bagaimana pengaruh harga terhadap keputusan siswa memilih SMK Negeri 1 Sumbawa Besar Angkatan 2017/2018?

3. Bagaimana pengaruh promosi terhadap keputusan siswa memilih SMK Negeri 1 Sumbawa Besar Angkatan 2017/2018?

4. Bagaimana pengaruh tempat terhadap keputusan siswa memilih SMK Negeri 1 Sumbawa Besar Angkatan 2017/2018?

5. Bagaimana pengaruh orang terhadap keputusan siswa memilih SMK Negeri 1 Sumbawa Besar Angkatan 2017/2018?

6. Bagaimana pengaruh proses terhadap keputusan siswa memilih SMK Negeri 1 Sumbawa Besar Angkatan 2017/2018?

7. Bagaimana pengaruh bukti fisik terhadap keputusan siswa memilih SMK Negeri 1 Sumbawa Besar Angkatan 2017/2018?

\section{METODE PENELITIAN}

\section{Rancangan Penelitian}

Jenis penelitian yang digunakan dalam penelitian ini adalah kuantitatif asosiatif. Dalam penelitian ini yang menjadi variabel independen adalah bauran pemasaran jasa (produk, harga, promosi, tempat orang, proses dan bukti fisik). Variabel dependen yaitu Keputusan Siswa Dalam Memilih SMK Negeri 1 Sumbawa Besar.

\section{Populasi dan Sampel}

Populasi dalam penelitian ini adalah seluruh siswa siswi SMK Negeri 1 Sumbawa Besar Angkatan 2017/2018. Teknik pengambilan sampel yang memberikan peluang yang sama bagi setiap unsur (anggota) atau cara pengambilan sampel secara acak. populasi yang dipilih menjadi anggota sampel. Dengan menggunakan metode simpel random sampling yakni pengambilan anggota sampel dari populasi dilakukan secara acak tanpa memperhatikan strata yang ada di dalam populasi itu.

\section{Analisis Data}

\section{Uji Validitas}

Uji validitas adalah menunjukkan sejauh mana suatu alat ukur mampu mengukur apa yang ingin diukur. Suatu kuisioner dikatakan valid jika pertanyaan pada kuesioner mampu untuk mengungkapkan sesuatu yang akan diukur oleh kuesioner tersebut.

\section{Uji Reliabilitas}

Reliabilitas adalah indeks yang menunjukan sejauh mana suatu alat ukur dapat dipercaya atau dapat diandalkan, Umar (2010:194).

\section{Uji Asumsi Klasik}

\section{UjiNormalitas}

Uji normalitas digunakan untuk mengetahui variabel independen dan variabel dependen berdistribusi normal. Untuk menguji data berdistribusi normal atau tidak, salah satu cara yang dapat digunakan yaitu menggunakan uji Kolmogrov- Smirnov Sujarweni, (2015:52).

\section{Uji Linearitas}

Uji linieritas adalah suatu pengujian untuk mengetahui apakah antara setiap variabel bebas dan variabel terikat bersifat linier atau tidak. Uji ini biasa digunakan sebagai prasyarat dalam analisis korelasi atau regresi linier.

\section{Uji Autokolerasi}

Autokolerasi adalah hubungan antara nilai suatu variabel dengan nilai variabel yang sama tetapi terjadi pada periode sebelumnya.

\section{Uji Heteroskedastisitas}

Gejala heteroskedastisitas diuji dengan metode Rank Spearman dengan cara menyusun regresi antara nilai absolut residual dengan variabel bebas (Sanusi, 2012: 141).

\section{Uji Multikolinearitas}


Uji multikolinearitas bertujuan untuk menguji apakah model regresi ditemukan adanya korelasi antar variabel bebas (independen) Sanusi, (2012: 136). Pendeteksian terhadap multikonealitas dapat dilakukan dengan melihat nilai Variance Infalating Factor (VIP) dari hasil analisis regresi.

Regresi Linear Berganda

Regresi linear berganda merupakan perluasan dari regresi linear sederhana, yaitu menambah jumlah variabel bebas yang sebelumnya hanya satu menjadi dua atau lebih variabel bebas (Sanusi, 2012:135). Dengan demikian, Regresi linear berganda dinyatakan dalam persamaan matematika sebagai berikut:

\section{$Y=a+b_{1} x_{1}+b_{2} x_{2}+b_{3} x_{3}+b_{4} x_{4}+b_{5} x_{5}+b_{6} x_{6}+b_{7} x_{7}+e$}

Keterangan:

$$
\begin{array}{ll}
\mathrm{Y} & =\text { Keputusan Memilih } \\
A & =\text { Parameter Intercept } \\
b_{1}, b_{2}, b_{3}, & b_{4}, b_{5}, b_{6}, b_{7},=\text { Koefisien Korelasi } \\
x_{1} & =\text { Produk } \\
x_{2} & =\text { Harga } \\
x_{3} & =\text { Promosi } \\
x_{4} & =\text { Tempat } \\
x_{5} & =\text { Orang } \\
x_{6} & =\text { Proses } \\
x_{7} & =\text { Bukti Fisik } \\
e & =\text { Variabel penganggu atau Eror }
\end{array}
$$

\section{PEMBAHASAN HASIL PENELITIAN}

\section{Gambaran Umum Obyek Penelitian}

\section{Sejarah Profil SMK Negeri 1 Sumbawa Besar}

SMK Negeri 1 Sumbawa Besar berawal dari SMKK Pertiwi yang berlokasi di jalan Mujair Kelurahan Seketeng dengan luas tanah $1600 \mathrm{n}^{2}$. Tanah tersebut berstatus milik daerah. Gedung SMKK Pertiwi terdiri dari 5 ruang belajar dengan bangunan semi permanen dan dipimpin oleh kepala Sekolah yang bernama ibu Desniar Adam, BA sampai dengan di Negerikan. Kemudian dengan persetujuan Kantor Wilayah Depdikbud Propinsi Nusa Tenggara Barat, tepatnya pada tanggal 30 Juli tahun 1980, SMKK Pertiwi telah diresmikan menjadi SMKK Negeri Sumbawa Besar dengan SK Mendikbud RI N0.0208/O/1980 tanggal 30 Juli 1980. Analisis Data

Tabel 4.2 Uji Normalitas

Unstandardized Residual

\begin{tabular}{llr}
\hline $\mathrm{N}$ & & 150 \\
Normal & Mean & .0000000 \\
Parameter & Std. & 2.77383283 \\
$\mathrm{~s}^{\mathrm{a}}$ & Deviation & .044 \\
Most & Absolute & .037 \\
Extreme & Positive & -.044 \\
Differenc & Negative & .539 \\
es & Kolmogorov-Smirnov Z & .933 \\
Asymp. Sig. (2-tailed)
\end{tabular}

Sumber: output spss
Berdasarkan tabel diatas diketahui bahwa nilai asymp. Sig $0.933>0,05$ sehingga dapat diketahui bahwa nilai semua variabel dalam penelitian ini berdistribusi normal.

\section{Uji Linearitas}

Tabel 4.3 Hasil Uji Linearitas

\begin{tabular}{ccc}
\hline Variabel & Sig & Keterangan \\
\hline $\mathrm{X} 1 \leftarrow \rightarrow \mathrm{Y}$ & 0.000 & Linear \\
$\mathrm{X} 2 \leftarrow \rightarrow \mathrm{Y}$ & 0.000 & Linear \\
$\mathrm{X} 3 \leftarrow \rightarrow \mathrm{Y}$ & 0.000 & Linear \\
$\mathrm{X} 4 \leftarrow \rightarrow \mathrm{Y}$ & 0.000 & Linear \\
$\mathrm{X} 5 \leftarrow \rightarrow \mathrm{Y}$ & 0.000 & Linear \\
$\mathrm{X} 6 \leftarrow \rightarrow \mathrm{Y}$ & 0.000 & Linear \\
$\mathrm{X} 7 \leftarrow \rightarrow \mathrm{Y}$ & 0.000 & Linear
\end{tabular}

Sumber: output SPSS 16.0

Dari tabel di atas, dapat diketahui bahwa hubungan antara variabel produk dengan keputusan memilih siswa bersifat linear, dengan nilai signifikansi 0.000 (lebih kecil dari 0.05). Hubungan antara variabel harga dengan keputusan memilih siswa bersifat linear, dengan nilai signifikansi 0.000 (lebih kecil dari 0.05). Hubungan antara variabel promosi dengan keputusan memilih siswa bersifat linear, dengan nilai signifikansi 0.000 (lebih kecil dari 0.05). Hubungan antara variabel tempat dengan keputusan memilih siswa bersifat linear, dengan nilai signifikan 0.000 (lebih kecil dari 0.05). Hubungan antara variabel orang dengan

\begin{tabular}{|c|c|c|c|c|c|}
\hline Model & $\mathrm{R}$ & $\begin{array}{c}\mathrm{R} \\
\text { Square }\end{array}$ & $\begin{array}{l}\text { Adjusted R } \\
\text { Square }\end{array}$ & $\begin{array}{l}\text { Std. } \\
\text { Error } \\
\text { of the } \\
\text { Estim } \\
\text { ate }\end{array}$ & $\begin{array}{c}\text { Durbi } \\
\text { n- } \\
\text { Wats } \\
\text { on }\end{array}$ \\
\hline 1 & 0.746 & 0.584 & 0.534 & $\begin{array}{r}0.041 \\
36\end{array}$ & 1.783 \\
\hline
\end{tabular}
keputusan memilih siswa bersifat linear, dengan nilai signifikan 0.000 (lebih kecil dari 0.05). Hubungan antara variabel proses dengan keputusan memilih siswa bersifat linear, dengan nilai signifikan 0.000 (lebih kecil dari 0.05). Hubungan antara variabel bukti fisik dengan keputusan memilih siswa bersifat linear, dengan nilai signifikan 0.000 (lebih kecil dari 0.05)

Uji Autokorelasi

Uji Autokorelasi

Tabel 4.4 Uji Autokorelasi

Dari hasil pengujian data pada tabel di atas, diperoleh hasil bahwa Durbin-Watson nya berjumlah 1.783 , nilai $\mathrm{d}_{\mathrm{L}}<\mathrm{d}_{\mathrm{W}}<$ $\mathrm{d}_{\mathrm{u}}, 1,636<1,783<1,831$ maka mengindikasikan pengujian tidak meyakinkan. 
Tabel 4.5 Autokorelasi (Data Transformasi)

\begin{tabular}{|c|c|c|c|c|c|}
\hline Model & $\mathrm{R}$ & $\begin{array}{c}\mathrm{R} \\
\text { Squar e }\end{array}$ & $\begin{array}{l}\text { Adjus } \\
\text { ted R } \\
\text { Squar } \\
\text { e }\end{array}$ & $\begin{array}{l}\text { Std. Error } \\
\text { of the } \\
\text { Estimate }\end{array}$ & $\begin{array}{l}\text { Durbin- } \\
\text { Watson }\end{array}$ \\
\hline 1 & 0.746 & 0.556 & 0.534 & .04136 & 1.883 \\
\hline
\end{tabular}

Sumber: output spss

Pada data pertama terjadi gejala autokorelasi jadi untuk mengatasi gejala autokorelasi dengan cara mentransformasi data dengan menggunakan log dari 150 untuk menghilangkan gejala autokorelasi yang dimana $\mathrm{d}_{\mathrm{u}}<\mathrm{d}<4-$ $\mathrm{d}_{\mathrm{u}}$ maka $1,831<1,883<2,169$ maka tidak terjadi autokorelasi.

\section{Uji Heteroskedastisitas}

Tabel 4.6Uji Heteroskedastisitas

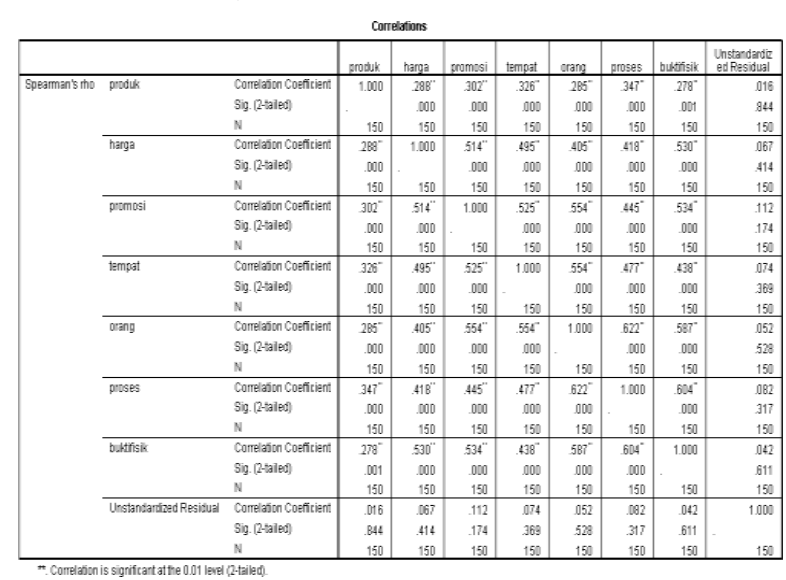

Berdasarkan data output di atas diketahui bahwa masingmasing variabel independen memiliki nilai sginifikan $>0,05$ maka tidak terjadi gejala heteroskedastisitas.

\section{Uji Multikolinearitas}

Tabel 4.7 Uji Multikolinearitas

\begin{tabular}{|c|c|c|c|}
\hline Variabel & Tolerance & VIF & Keterangan \\
\hline Produk & 0,859 & 1,165 & $\begin{array}{l}\text { Tidak terjadi } \\
\text { multikolinearitas }\end{array}$ \\
\hline Harga & 0,714 & 1,401 & $\begin{array}{l}\text { Tidak terjadi } \\
\text { multikolinearitas }\end{array}$ \\
\hline Promosi & 0,624 & 1,602 & $\begin{array}{l}\text { Tidak terjadi } \\
\text { multikolinearitas }\end{array}$ \\
\hline Tempat & 0,526 & 1,900 & $\begin{array}{l}\text { Tidak terjadi } \\
\text { multikolinearitas }\end{array}$ \\
\hline Orang & 0,528 & 1,895 & $\begin{array}{l}\text { Tidak terjadi } \\
\text { multikolinearitas }\end{array}$ \\
\hline Proses & 0,772 & 1,295 & $\begin{array}{l}\text { Tidak terjadi } \\
\text { multikolinearitas }\end{array}$ \\
\hline $\begin{array}{l}\text { Bukti } \\
\text { Fisik }\end{array}$ & 0,570 & 1,755 & $\begin{array}{l}\text { Tidak terjadi } \\
\text { multikolinearitas }\end{array}$ \\
\hline
\end{tabular}

Berdasarkan hasil pengujian di atas diketahui nilai VIF masing-masing variabel $<10$ maka disimpulkan tidak terjadi gangguan multikolinearitas atau dengan kata lain model regresi ini terbebas dari gejala multikolinearitas.

\section{Uji Regresi Linear Berganda}

Tabel 4.8 Hasil Uji Regresi Linear Berganda

\begin{tabular}{lllll}
\hline $\mathrm{c}$ & $\begin{array}{l}\text { Koefi } \\
\text { sien } \\
\text { regresi }\end{array}$ & $\begin{array}{l}\text { Stan dan } \\
\text { eror }\end{array}$ & $\begin{array}{l}\text { thitu } \\
\text { ng }\end{array}$ & Sig \\
& & & & \\
\hline Produk (X1) & 0,064 & 0,069 & 0,936 & 0,351 \\
Harga(X2) & 0,051 & 0,031 & 1,638 & 0,104 \\
Promosi (X3) & 0,061 & 0,036 & 1,704 & 0,091 \\
Tempat (X4) & 0,214 & 0,062 & 3,433 & 0,001 \\
Orang (X5) & 0,099 & 0,051 & 1,935 & 0,055 \\
Proses (X6) & 0,049 & 0,046 & 1,064 & 0,289 \\
Bukti Fisik & 0,172 & 0,051 & 3,341 & 0,001 \\
(X7) & & & & \\
& & $: 0,784$ & & \\
Konstanta & & & \\
Koefisien Determinasi $\left(\mathrm{R}^{2}\right): 0,566 \mathrm{~N}$ & 150 & \\
\hline
\end{tabular}

Berdasarkan tabel 4.5 maka dapat diketahui persamaan regresi yang terbentuk.

\section{Pengujian Hipotesis}

a. Pengujian hipotesis: Produk tidak berpengaruh dan tidak signifikan terhadap keputusan memilih

Variabel produk memiliki nilai thitung sebesar 0,936 lebih kecil dari nilai tabel yaitu 1,655 dengan tingkat signifikan $0,351>0,05$. Hasil ini berarti bahwa $\mathrm{H}_{0}$ diterima atau hipotesis yang menyatakan produk secara parsial tidak berpengaruh terhadap keputusan memilih ditolak.

b. Pengujian hipotesis: Harga tidak berpengaruh dan tidak signifikan terhadap keputusan memilih.

Variabel harga memiliki niali thitung $<t_{\text {tabel }}$ sebesar 1,638 lebih kecil dari nilai tabel yaitu 1,655 dengan tingkat signifikan $0,104>0,05$. Hasil ini berarti bahwa $\mathrm{H}_{0}$ diterima atau hipotesis yang menyatakan produk secara parsial tidak berpengaruh terhadap keputusan memilih ditolak.

c. Pengujian hipotesis: promosi berpengaruh dan tidak signifikan terhadap keputusan memilih

Variabel promosi memiliki nilai thitung $>t_{\text {tabel }}$ sebesar 1,704 lebih besar dari nilai tabel yaitu 1,655 dengan tingkat signifikan 0,091>0,05. Hasil ini berarti bahwa $\mathrm{H}_{0}$ ditolak atau hipotesis yang menyatakan produk secara parsial tidak berpengaruh terhadap keputusan memilih diterima

d. Pengujian hipotesis: tempat berpengaruh signifikan terhadap keputusan memilih

Variabel tempat memiliki nilai $t_{\text {hitung }}>t_{\text {tabel }}$ sebesar 3,433 lebih besar dari nilai tabel yaitu 1,655 dengan tingkat signifikan $0,001<0,05$. Hasil ini berarti bahwa $\mathrm{H}_{0}$ ditolak atau hipotesis yang menyatakan produk secara parsial berpengaruh terhadap keputusan memilih diterima

e. Pengujian hipotesis: orang berpengaruh dan tidak signifikan terhadap keputusan memilih

Variabel orang memiliki nilai thitung $>$ tabel sebesar 
1,935 lebih besar dari nilai tabel yaitu 1,655 dengan tingkat signifikan $0,055>0,05$. Hasil ini berarti bahwa $\mathrm{H}_{0}$ ditolak atau hipotesis yang menyatakan produk secara parsial tidak berpengaruh terhadap keputusan memilih diterima.

f. Pengujian hipotesis: proses tidak berpengaruh dan tidak signifikan terhadap keputusan memilih

Variabel promosi memiliki nilai thitung $<$ tabel sebesar 1,064 lebih kecil dari nilai tabel yaitu 1,655 dengan tingkat signifikan $0,289>0,05$. Hasil ini berarti bahwa $\mathrm{H}_{0}$ diterima atau hipotesis yang menyatakan produk secara parsial tidak berpengaruh terhadap keputusan memilih ditolak.

g. Pengujian hipotesis: bukti fisik berpengaruh signifikan terhadap keputusan memilih

Variabel promosi memiliki nilai thitung $>t_{\text {tabel }}$ sebesar 3,341 lebih besar dari nilai tabel yaitu 1,655 dengan tingkat signifikan $0,001<0,05$. Hasil ini berarti bahwa $\mathrm{H}_{0}$ ditolak atau hipotesis yang menyatakan produk secara parsial tidak berpengaruh terhadap keputusan memilih ditolak.

\section{Penutup}

\section{Kesimpulan}

Berdasarkan pada hasil penelitian dan pembahasan yang telah diuraikan sebelumnya maka disimpulkan sebagai berikut:

1. Berdasarkan hasil perhitungan yang telah dilakukan secara parsial variabel produk tidak berpengaruh dan tidak signifikan terhadap keputusan siswa memilih SMK Negeri 1 Sumbawa Besar (Studi Kasus Angkatan 2017/2018)

2. Berdasarkan hasil perhitungan yang telah dilakukan secara parsial variabel harga tidak berpengaruh dan tidak signifikan terhadap keputusan siswa memilih SMK Negeri 1 Sumbawa Besar (Studi Kasus Angkatan 2017/2018).

3. Berdasarkan hasil perhitungan yang telah dilakukan secara parsial variabel promosi tidak berpengaruh dan tidak signifikan terhadap keputusan siswa memilih SMK Negeri 1 Sumbawa Besar (Studi Kasus Angkatan 2017/2018).

4. Berdasarkan hasil perhitungan yang telah dilakukan secara parsial variabel tempat berpengaruh signifikan terhadap keputusan siswa memilih SMK Negeri 1 Sumbawa Besar (Studi Kasus Angkatan 2017/2018).

5. Berdasarkan hasil perhitungan yang telah dilakukan secara parsial variabel orang berpengaruh dan tidak signifikan terhadap keputusan siswa memilih SMK Negeri 1 Sumbawa Besar (Studi Kasus Angkatan 2017/2018).

6. Berdasarkan hasil perhitungan yang telah dilakukan secara parsial variabel proses tidak berpengaruh terhadap keputusan siswa memilih SMK Negeri
1 Sumbawa Besar (Studi kasus angkatan 2017/2018).

7. Berdasarkan hasil perhitungan yang telah dilakukan secara parsial variabel bukti fisik berpengaruh signifikan terhadap keputusan siswa memilih SMK Negeri 1 Sumbawa Besar (Studi Kasus Angkatan 2017/2018).

\section{Daftar Pustaka}

Arikunto, Suharsimi. (2006). "Prosedur Penelitian Suatu Pendekatan Praktik". Jakarta: Rineka Cipta.

Arsyad, M. (2010). “Analisis Pengaruh Marketing Mix Terhadap Keputusan Mahasiswa Memilih Akpindo Jakarta". Jurnal Ilmiah Panorama Nusantara. Vol.9.

Dakhi, Pskalis. (2017). "Pengaruh Bauran Pemasaran Jasa Terhadap Keputusan Mahasiswa Memilih Kuliah Di STIE NIAS SELATAN" Jurnal Ekonomi dan Bisnis Nias Selatan. Vol.1, No.1

Hasan, Ali (2013). Marketing dan kasus-kasus pilihan. Yogyakarta: CAPS

Hery, (2013). Pengantar Manajemen. Jakarta: Gata Media.

Hukama, La Diadhan dan Zainal Zawir Simon (2018), "Pengaruh Bauran Pemasaran Terhadap Keputusan Mahasiswa Sekolah SMK Di Kota Pelangka Raya”.

Jurnal Sains Manajemen. Vol 3, No. 2:95. Zahara, Syamsul Bachri dan Podungge Salim

Emil. (2015). "Pengaruh Bauran Pemasaran Jasa Terhadap Keputusan Mahasiswa Memilih STMIK BINA MULIA PALU". Jurnal.Vol3.No.10

Memilih Fakultas Ekonomi Universitas Yarsi” Jurnal Ilmiah FE-UMM. Vol12.No1.

Kotler Philip \& Keller Kevin. (2007). Manajemen Pemasaran (Edisi 12 Jilid 1). PT.INDEKS.

Putra Eka Syailendra, Wahyuni Sri dan Rinanda Desta Silvia. (2012). "Pengaruh Bauran Pemasaran Jasa (Marketing Mix Jasa) Terhadap Keputusan Konsumen Dalam Memilih Jasa Pendidikan Bahasa Inggris di Melbourne English School Padang”. Jurnal SSI. Vol 2.No9.

Santoso, Singgih. (2011). Mastering SPSS Versi 19. Jakarta : Elex Media Komputindo

Sanusi, Anwar. (2012). Methodologi Penelitian Bisnis. Jakarta: Salemba Empat.

Siregar, Syofian. (2013). Metode Penelitian Kuantitatif. Jakarta: PT Fajar Interpratama Mandiri.

Siswanto. H. B. (2007). Pengantar Manajemen (Teori, Praktik, dan Riset Pendidikan. Jakarta : Bumi Aksara.

Siswanto. H. B. (2007). Pengantar Manajemen (Teori, 
Praktik, dan Riset Pendidikan. Jakarta : Bumi Aksara.

Sugiyono, (2007). Metode Penelitian Kuantitatif, Kualitatif, dan $R \& D$. Bandung: Alfabeta.

Tangilisan, G. Oroh., S.G. Soegoto. A.S, (2014).

"Bauran Pemasaran Jasa Pendidikan Pengaruhnya Terhadap Keputusan Siswa Dalam
Memilih Sekolah Di Smk N 1 Manado". Jurnal EMBA. Vol.2 No.4.

Tjiptono, Fandy. (2011). Strategi Pemasaran Cetakan Ketiga, Yogyakarta: Andi Offset.

Wati, Dewi Tiwi. (2014). “Analisis Pengaruh FaktorFaktor Bauran Pemasaran Jas Terhadap Keputusan Siswa Memilih. 
